Book Review

\title{
Tim William Machan. (2009). Language Anxiety: Conflict and Change in the History of English. Oxford, UK: Oxford University Press
}

\author{
Reviewed by Nadeane Trowse \\ University of the Fraser Valley, Canada
}

Tim William Machan's book Language Anxiety: Conflict and Change in the History of English illuminates the status of English in the context of a conflictual history. It has been on my desk for some time while I have engaged in inner and outer debate about it, mostly about why I find it so rich and students find it less so. To support my teaching of the history of the English language, I wanted a carefully researched book that displayed English and its evolution as a site of difficulty as well as opportunity. I wanted a book that could show that English is a language whose history is laden with issues of colonialism, hegemony, power imbalances, and prescriptivism-the latter complicit in all the preceding. I wanted a book that would detail the need to nuance notions of grammar and its unproblematic goodness. I wanted a book to ground, historically and socio-linguistically, Deborah Cameron's (1995) arguments in Verbal Hygiene. Machan provides all those things. This review celebrates Machan's undoubted achievement in producing such a book, while noting that I still search for a book more persuasive to students.

My hopes for Language Anxiety to perform in textbook-like ways were not entirely ungrounded. Machan precedes his chapters with a forward including the IPA phonetic symbols and some indications of how to use them, suggesting he anticipates classroom uses for his book, or at least invites non-specialist readers. But clearly his intention is to situate his assembly of detail in the service of making supported arguments about how the history of English can play into current understandings rather than for teaching use, per se.

Machan raises issues of great linguistic and historic interest by also linking them to presentday tussles, for example regarding the significance of linguistic phenomena and language user uptake of authors like Lynne Truss (2003). Truss's sheer popularity-including her fans' strong appetite for her prescriptivism-celebrating panda joke-attests to an unnuanced appetite for grammatical correctness. Machan scaffolds his argument on recognizing the existence of such forces, stating "how anxiety over language change and variation has trans-historically motivated and underwritten sociopolitical behaviour, ideological formation, and mythological construction 
Volume 26, 2016

http://journals.sfu.ca/cjsdw

- how it has been largely a constant in the Anglophone world" (p. 22). That is, his project does not debate whether language usage might have social implications but situates that presupposition in linguistic history.

Chapter One, "Language Change and Response," defeats simplistic notions of what language change means regarding who speaks, how, and when-in other words, who is entitled to make what sounds in English. Machan suggests language anxiety is a response to language undergoing change on various fronts. While this is far from news, it is an important linkage to remember. His representative anecdote describes an encounter with media asking what accent was right for an American character in The Patriot, a film about the American War of Independence. Machan relates that he explained the complexities of language change, and that an accent like PDEAmerican would be acceptable. But to him, the question of which accent is historically right is less interesting than why it matters to an American interviewer. Thus he embarks on the issue of language anxiety, linking it to change and the shifts in power structures that often initiate or result from it.

Chapter Two, "A Moveable Speech," views the history of language change anxiety through the lens of phonological, morphological, lexical, and syntactical details. Under the subheading "The regularities of grammar" Machan offers reassurance, citing Edward Sapir's assurance that "all grammars leak" (p. 31). This enables him to tackle prescriptivism and, rather than chastising prescriptivists, display the consequences of prescription. He notes that modern prescriptivists tend to express "indignant response to unnatural change". His examination of prescriptivism importantly reminds us that there are prescriptive uses of descriptivism too, saying "the interpretive maneuver of deriving one [form] from another. . . can misleadingly use the objectivity of descriptive grammar to present what is ultimately a presumptive [or erroneous] judgement about which form is normative" (p. 52). Machan ends the detail-rich chapter with questions about how sociolinguistic meanings and values are assigned. He is less interested in change itself than, for example, why "some kinds of structured, irrational variation [in language] engender hostility, while other kinds do not" (p. 80).

The Tower of Babel story and its biblical precursor from Genesis that accounts for the dispersal of Noah's descendants ground Machan's Chapter Three, "Narratives of Change." These types of story-making powerfully show the narrative enshrining attitudes to language change and variation. While associating language variation with Noah's descendants as they disperse is just another feature of using language for naming and group-identification, the Tower of Babel myth at once argues for the power of the unity of language and punishes the desire for such 
power. Machan teases out this myth's historical implications for language-related attitudes and action in colonization. He links the timing of the replication of images of the Tower of Babel with increases in travel/colonization that for Europeans greatly expanded the number of known and distinct languages, and destabilized the idea of a unitary origin for humanity. This suggests anxious ping-ponging between the idea that language change is inevitable (but not necessarily good) and that language change is unnatural (and should be punished or corrected). Machan adds that since $12^{\text {th }}$ century thinking held that all languages arose from Hebrew, moral implications surround departures from Hebrew. Hebrew was "natural" while all other languages were not, recruiting religion to warrant (and regret the lack of) language stability.

Chapter Four, "Policy and Politics" explores how language change is associated with punitive attitudes. While linguists are comfortable with the idea that language change happens in "geological time," Machan says this view distorts agency in language users. He considers phenomena like Verner's Law regarding consonant change. Since what he calls "linguistic foresight" is illusory (speakers don't know they are speaking at the beginning, middle, or end of a continuum of language change), speakers may be anxious about the variations they perceive, but they have little agency to decide about their part in change except by applauding or deploring other speakers' usage. Machan links these ideas with discussion of the Standard, and standardization. He also argues, using the situation of Spanish speakers in an ideologically unilingual (English) US, that if speakers "are victims of change in the language they speak, the language itself, both in structure and pragmatics, is certainly changed by them" (p. 134). He complicates the situatedness of language use further: "if religious and civic policies guide the language use of individuals, the policies themselves are ultimately the creation of individuals" (p. 135). Thus he ascribes agency to those we could view as simply oppressed by language policies.

Machan explores issues raised by language planning historically, citing Alfred the Great's language promotion and the rise of "English" as a banner of resistance for the Anglo-Saxon side during the era of Danish incursions. He links that effort to save English with more recent language extinction threats, and policies that arise to oppose such extinctions. Machan adds the Lollard situation in late Medieval England when tensions around literacy and language abounded, involving religious divisions about the value of literacy, particularly literacy in vernacular English. Moving to current examples, Machan offers the Official Languages Act in Canada to illustrate that linguistic variation is maintained symbolically, while the "primary point of contention remains non-linguistic" (p. 166). He tackles such problems of national identity and 
their relationship to language by exploring whether language is the very essence of national thought, the symbol of belonging, or the mandated glue intended to bind the nation together. Noting that "language policies, like literary effects, are ways to generate pragmatic weight and invest social meaning," he links these paradoxically connected propositions to policies of colonial projects where a dominant language is mandated, and indigenous, or other small groups of language users are suppressed, precisely because their languages do not reflect the imagined, required national identity (p. 184).

By Chapter Five, Machan has thoroughly persuaded readers that paradox rather than one right answer is the answer. He approaches the "right" through ideas about the Standard, as the Standard gets enshrined in dictionaries and people's enduring belief that dictionaries are "right" rather than descriptive of usage patterns. He shows the historical associations with correctness; grammatical correctness, rather than a feature of language, became a moral or ethical puzzle which humans have been obliged to get right. He relies on paradox to situate the historical relationship between grammatical rightness (especially as encoded in dictionaries and instructional manuals) and mere usage-created patterns. That is, while language is not one absolute unchanging thing, using language as if it were, reflective of the situation and status of the language user, is an obligation, however impossible. This helps me understand the social action of Truss's joke in Eats, Shoots, and Leaves (2003), regarding the poorly punctuated wildlife guidebook. Truss endorses the Standard and ridicules those not practicing it with skill, not just because the errors of others amuse us, but that error-makers must be shamed for their own good.

Machan also suggests that anxiety over language instability increased over time. That is, variation and change became more anxiety-producing as we moved closer to the contemporary era. This includes the match between orthography and the Standard as well as the paradoxical problems caused by the importation of terms from classical languages of authority like Latin and Greek, especially as 'learned borrowings' creating lexical instabilities. Machan notes while English escaped the extremes of standardization produced by having a National Academy, charged with creating invariability and 'rightness', social forces still opposed linguistic deviance as if it were social deviance, linking the two and imagining the perils of destabilization that both represented. Further, the desirability of a Standard is implied, he suggests, by the plurality of distinct dialects in England as perceived by writers in the Early Modern period for whom all dialect variation was deviant. 
In Chapter Six, "Fixing English," Machan situates dictionaries, standards, and the costs and benefits resulting from 'fixing' in David Lightfoot's notion that language "[is] a mythical, imaginary creature... [that] may be a convenient fiction... [but] is not a coherent, definable entity" (p. 241). He indicates that we study linguistic change and variation not to define the language so much as to define the conditions and situation containing it. Machan's concern in this chapter is to further the discussion about repercussions and consequences of all relationships with Standard English and to suggests a possible way to escape from too much paradox wherein we "allow language to stand in for non-linguistic concerns" (p. 246).

Machan's book clearly offers richly detailed and supported connections between sociolinguistic analyses of language phenomena and the history of the English language. He illuminates current language-related moral or ethical social issues; the language related components of immigration anxiety; language restriction or prescriptivism and human rights; gendered language complexities; and language legitimacy or illegitimacy. Why is his book then not the popular offering I expected it to be for students? As Cameron's Verbal Hygiene resists essentializing student questions about whether verbal hygiene is bad or good, Machan resists giving unnuanced answers. And perhaps with this need to examine or hold conflicting ideas, the book itself creates anxiety beyond the comfort level of students who are already overburdened with paradoxes of their lives and who might find less nuanced material attractive.

\section{References}

Cameron, D. (1995). Verbal hygiene. London, England: Routledge.

Truss, L. (2003). Eats, shoots \& leaves: The zero tolerance approach to punctuation. New York, NY: Gotham. 